\title{
March/April 2016
}

Published online: 22 February 2016

(C) Springer Science+Business Media New York 2016

The Federal Interagency Forum on Child and Family Statistics has released its 2015 report, America's Children: Key National Indicators of Well-Being. The report which runs more than 200 pages "identifies seven major domains that characterize the well-being of a child and influence the likelihood that child will grow to be a well-educated, economically secure, productive, and healthy adult. The seven domains are family and social environment, economic circumstances, health care, physical environment and safety, behavior, education, and health." Relying on dozens of survey studies, the report is intended as a gateway "to acquaint readers with concepts found in other, more technical or comprehensive reports." Among highlights:

- There were 73.6 million children (ages $0-17$ ) in the United States in 2014, 1.2 million more than in 2000.

- In $2014,69 \%$ of children lived with two parents $(64 \%$ with two married parents and $4 \%$ with two unmarried cohabitating parents). Twenty four percent lived with only their mothers, $4 \%$ lived with only their fathers, and $4 \%$ lived without a parent in the household.

- In 2013, the adolescent birth rate was 12 per 1000 adolescents ages $15-17$, a record low for the country.

- Twenty percent of all children ages 0-17 (14.7 million) lived in poverty in 2013, down from $22 \%$ in 2012 . This was the first time since 2000 that the child poverty rate declined.

- The percentage of children without health insurance at the time of interview decreased from $14 \%$ in 1993 to $7 \%$ in 2013.

- In 2013 , about $70 \%$ of children ages $19-35$ months received the recommended combined seven-vaccine immunization series.
- In 2011-2012, about $18 \%$ of children ages 6-11 and $21 \%$ of adolescents ages $12-17$ were obese.

(Access at: http://www.childstats.gov/americaschildren/ index.asp)

\section{America's Drug Overdose Epidemic}

According to Rachel DiCarlo Currie, the nationwide rate of deaths from drug overdoses rose by $137 \%$ between 2000 and 2014, with a $200 \%$ rise in overdose deaths from opioids such as heroin and prescription pain killers. The state of New Hampshire stands out with the rate of overdose deaths increasing from 8.7 per 100,000 in 2002 to 26.2 per 100,000 in 2014 . Between 2013 and 2014 it increased 74\%.

Currie writes, "What is the solution? Among both liberal and conservative policymakers, there's a growing push to deal with nonviolent drug users outside the criminal-justice system. No question, if we're trying to help an addict get clean, it makes more sense to put him in a treatment center rather than a prison cell." Yet this trend, some studies suggest, does not fully meet the challenges of reducing recidivism and addiction. Currie refers readers to Project HOPE (Hawaii's Opportunity Probation and Enforcement program), a program within the criminal-justice system, which succeeded in reducing arrest rates of addicts, maintaining better oversight in general. Like most programs, the proof will be in its replication in other states now underway. (Access at: http://iwf.org/blog/2799235/Confronting-America\%E2\% 80\%99s-Drug-Overdose-Epidemic) 